\title{
A Case of Aspergillus Clival Abscess Treated by Endoscopic Removal
}

\author{
Jong Sei Kim¹, Kyu-Sun Jang ${ }^{1}$, Yoon Kyoung So ${ }^{2}$, and Sang Duk Hong ${ }^{1}$ \\ ${ }^{1}$ Department of Otorhinolaryngology-Head and Neck Surgery, Samsung Medical Center, Sungkyunkwan University School of Medicine, \\ Seoul; and ${ }^{2}$ Department of Otolaryngology, Ilsan Paik Hospital, Inje University College of Medicine, Goyang, Korea
}

\section{진균성 사대 농양의 내시경적 제거 증례 1예}

\author{
김종세 ${ }^{1} \cdot$ 장규선 ${ }^{1} \cdot$ 소윤경 ${ }^{2} \cdot$ 홍상덕 ${ }^{1}$ \\ 성균관대학교 의과대학 삼성서울병원 이비인후과학교실, ${ }^{1}$ 인제대학교 의과대학 일산백병원 이비인후과학교실
}

\author{
Received April 23, 2014 \\ Revised June 17, 2014 \\ Accepted June 18, 2014 \\ Address for correspondence \\ Sang Duk Hong, MD \\ Department of Otorhinolaryngology- \\ Head and Neck Surgery, \\ Samsung Medical Center, \\ Sungkyunkwan University \\ School of Medicine, 81 Irwon-ro, \\ Gangnam-gu, Seoul 135-710, Korea \\ Tel +82-2-3410-3447 \\ Fax $+82-2-3410-3879$ \\ E-mail kkam97@gmail.com
}

Aspergillus clival abscess, especially without a sphenoid sinus lesion, is a very rare infection of central nervous system. In this report, we describe the successful treatment of a patient with aspergillus clival abscess. A 63 -year-old man was referred to our hospital with the diagnosis of sphenoid mass lesion in magnetic resonance image accompanied by headache and diplopia. The computed tomography scan revealed a clival cystic lesion without connection with the sphenoid sinus. The patient underwent the endoscopic endonasal clival approach and histopathological examination revealed aspergillosis. Postoperatively, the patient was given IV amphotericin-B for 2 weeks and oral voriconazole for 3 months. After surgery, patient's headache and diplopia disappeared. Aspergillus abscess originating from the skull base is rare but has a high mortality rate. Histopathological confirmation via endonasal approach and intensive antifungal therapy should be started for a successful treatment.

Korean J Otorhinolaryngol-Head Neck Surg 2015;58(1):52-6

Key Words Aspergillosis · Clivus · Endoscopy.

\section{서 론}

최근 비 내시경 수술의 발전으로 뇌하수체 및 두개저의 경 비강적 접근이 널리 사용되고 있다. 사골와, 접형동 등의 결 손으로 인한 상행 감염으로 인한 경막 외 농양이나 두개내 농 양은 신경외과적 개두술보다는 경 비강적 배농술이 수술 후 합병증을 줄이면서 간편하게 시행될 수 있다. 접형동의 농양 과 비교하여 사대는 두개내 병변의 드문 위치이며 특히나 이 위치의 진균성 농양의 발병은 매우 드물다. 접형동으로부터 파 급된 사대의 진균성 농양은 이전의 문헌에서 보고된바 있으나 독립된 사대의 진균성 농양은 보고된 바가 없다. ${ }^{1)}$ 저자들은 사대에서 유발된 진균성 농양을 경 비강 내시경 수술로 제거 한 후 치유된 환자를 경험하여 이에 대하여 문헌고찰과 함께 보고하는 바이다.

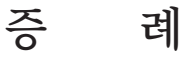

63세 남자환자로 1 개월간 지속되는 측 두부의 두통과 복시 를 주소로 본원 신경외과 외래를 내원하였다. 내원 당시 열은 없었으며, 뇌막자극증상은 보이지 않았고 의식은 명료하였 다. 혈액검사상 백혈구증가 $(154000 / \mu \mathrm{L})$ 외에 염증관련 지표 (erythrocyte sedimentation rate, C-reactive protein) 등 다 른 이상 소견은 보이지 않았다. 안과 검진상 시력 및 시야는 정 상이었으며, 사시 정도를 프리즘 각을 이용한 객관적 diopter 로 평가하는 Krimsky test에서 정면 주시시 30 prism diopter (PD), 우측 측면 주시시에 $50 \mathrm{PD}$ 의 내사시가 관찰되었다. 외 향근 운동은 우측 측면 주시시 우측에서만 약 $25 \%$ 의 제한을 보였으며, 다른 모든 방향에서 정상 소견을 보여, 우측 외향신 경 마비로 진단할 수 있었다. 당뇨 등 면역저하를 의심할 만한 
특이 병력은 없었다. 뇌 자기공명영상 소견상 뇌 실질로 이어 지지 않고 안장을 위쪽으로 전위시키고 있는 접형동의 확장 성 병변(Fig. 1)이 관찰되었다. T1 강조영상에서 저 신호강도, 그리고 $\mathrm{T} 2$ 강조영상에서 고 신호강도를 보여 접형동 점액낭 종이 가장 의심되었으며, 이에 대하여 이비인후과로 협진 의뢰 되었다. 하지만 본 저자가 판단하기에 컴퓨터단층촬영 소견 상, 사골동을 비롯한 다른 부비동 내에 병변은 관찰되지 않았
고, 접형동의 후 벽은 유지된 상태였으며, 낭종과 전면으로 밀린 작은 접형동이 분리되어있는 양상으로 두개저 기원의 낭종의 가능성이 높아보였다(Fig. 2). 영상검사 소견상 진단이 불분명한 상태로 경 비강 내시경적 조직검사 및 낭종 제거를 계획하였다. 전신마취하에 앙와위로 수술을 진행하였으며 주변 구조물들의 위치를 정확히 파악하기 위하여 컴퓨터단층 촬영 영상을 이용한 항법장치(image guided surgery, naviga-
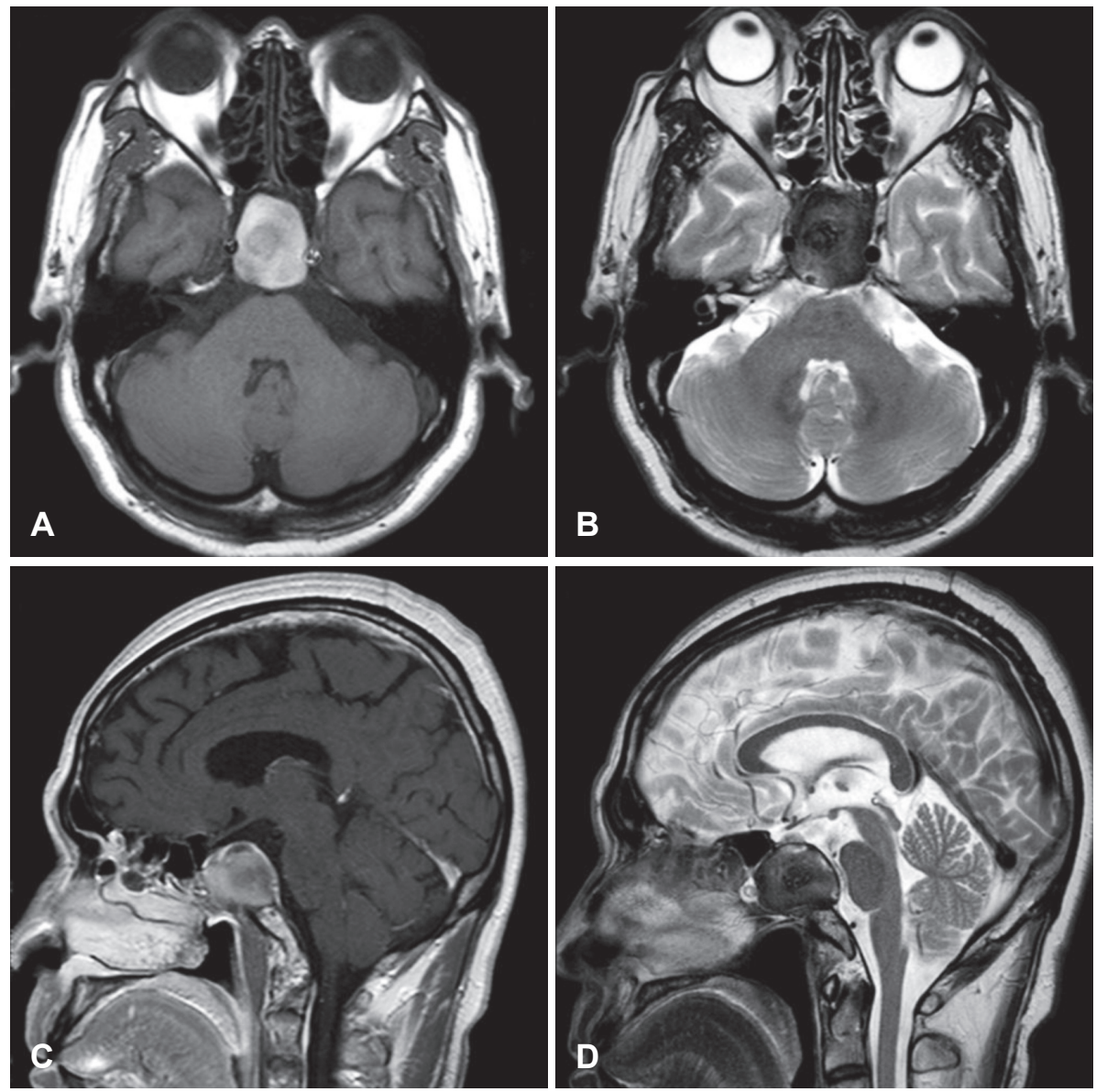

Fig. 1. Axial magnetic resonance (MR) images revealing a homogeneous high signal intensity mass in sphenoid sinus on T1-weighted (A) and low signal intensity on T2-weighted (B) images. Sagittal T1-weighted MR image with gadolinium enhancement (C) and T2-weighted MR image (D) revealing that pituitary gland was displaced but intact.
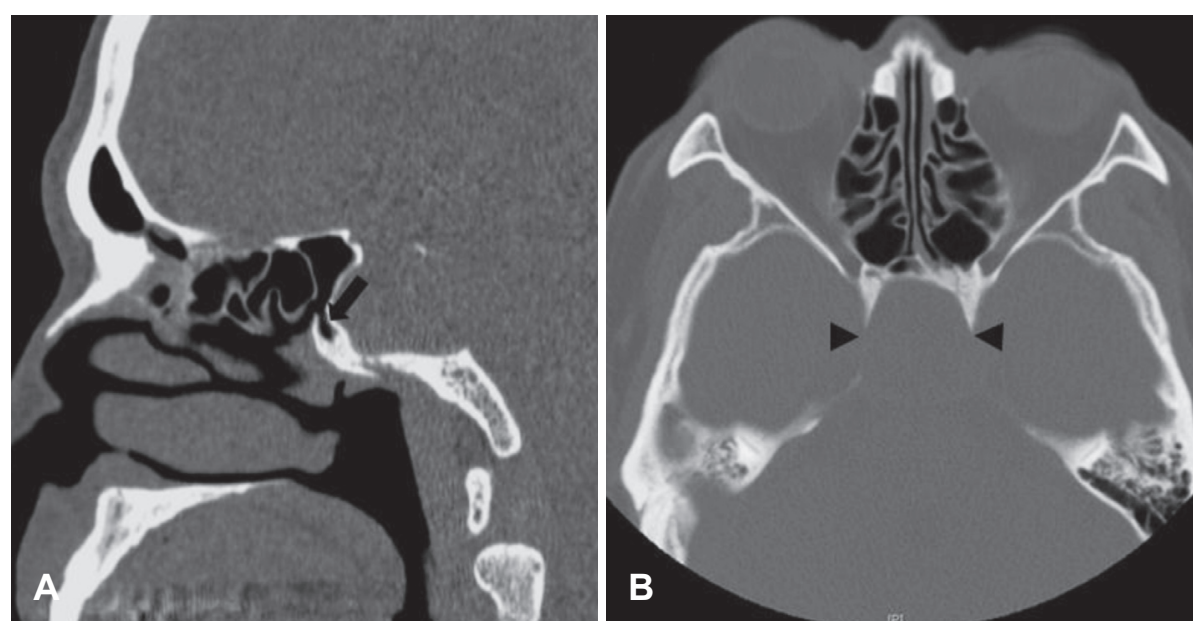

Fig. 2. Computed tomography scans: small anterior displaced sphenoid sinus (arrow) in sagittal image (A) and cystic lesion with marked bony remodeling (arrowheads) in axial image (B) were displayed. 
Fig. 3. Intraoperative endoscopic view of the transsphenoidal approach showing there is no defect in the posterior wall of sphenoid (A). After removal the anterior wall of clivus, the muddy like material was founded (B).
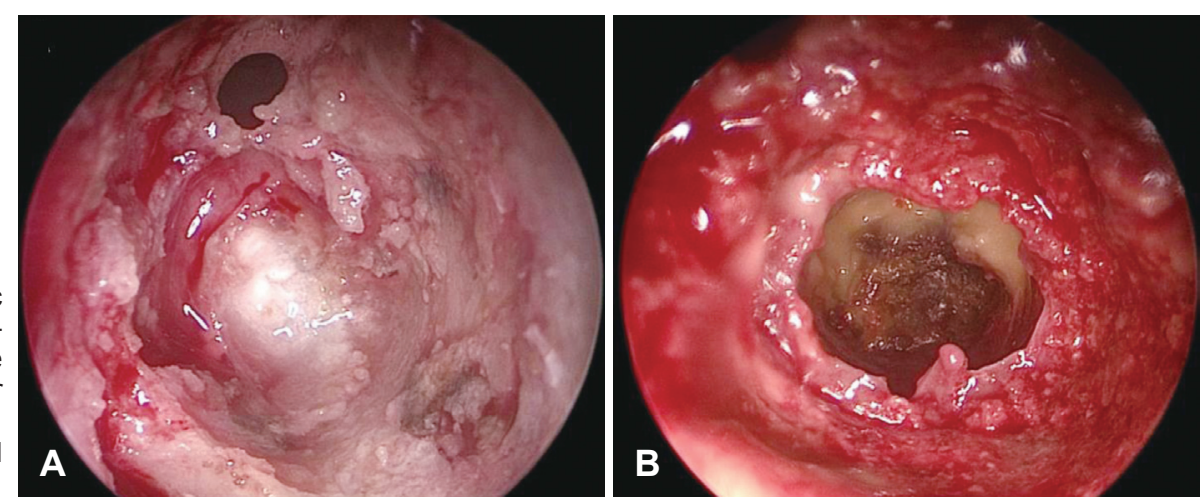

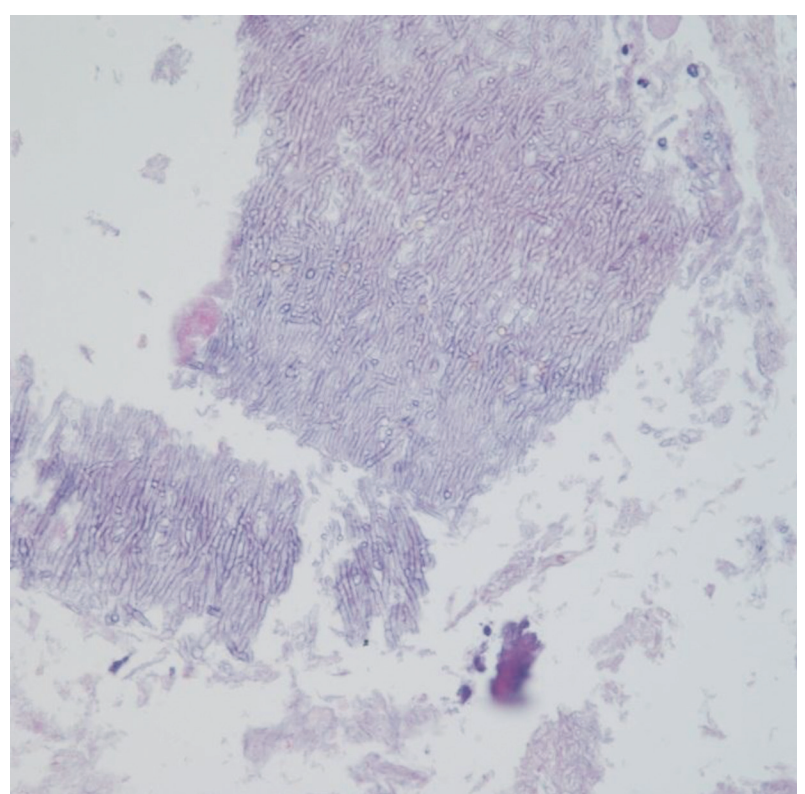

Fig. 4. Histopathologic finding (H\&E stain, $\times 400)$. The thick pus material showing the dischotomously branching and septating hypae suitable for aspergillosis.

tion guided surgery)를 사용하였다. ${ }^{2)}$ 먼저 우측 경 비강 접 형동 개방술을 시행하였다. 접형동내의 점막 부종은 있었으 나 접형동 후 벽의 결손은 보이지 않았고 접형동과 병변과의 연결 또한 관찰되지 않았다(Fig. $3 \mathrm{~A}$ ). 접형동의 후골 벽을 고 속드릴을 이용하여 제거하자, 낭종의 벽이 확인되었고, 큐렛 등을 이용하여 낭종 벽을 일부 제거하였다(Fig. $3 \mathrm{~B}$ ). 낭종 내 부에는 어두운 갈색 빛깔의 점도가 높은 침전물로 가득 차 있는 양상이었다. 내부 침전물의 완전한 제거를 위하여 접형 골문(rostrum)을 일부 제거한 후 양측 비강을 통한 경접형 동 사대 접근법으로 범위를 넓혀서 수술을 진행하였다. 농양 내부 침전물들과 괴사성 연조직들을 조심스럽게 제거한 후 조직검사를 시행하였다. 수차례 생리식염수로 세척하여 농양 내부 침전물의 완전한 제거를 확인하였으며 정상적인 경막과 내경동맥의 박동을 확인할 수 있었으며 뇌척수액 누출은 보이 지 않았다. 내부 침전물의 배양검사 및 조직검사결과 아스페 르길루스(aspergillus)에 의한 농양으로 확인되었다(Fig. 4). 환자는 수술 후 주관적인 복시와 두통은 바로 호전되었으며, 객관적인 안과적 검진(Krimsky test)상으로는 약 수술 1 개 월 후 수술 전에 보였던 우측 주시시의 내사시는 모두 호전되 었다. 진균 감염이 두개저에서 기원한 것으로 판단하여, 중추 신경 진균 감염에 준하여 2주간 정맥 내 amphotericin 투약을 시행하였고, 이후 경구 voriconazole을 3개월간 투여 후 치료 종결하였다. 수술 2 개월 후 추적관찰 뇌 자기공명영상, 컴퓨터 단층촬영 검사상(Fig. 5) 재발소견은 관찰되지 않으며, 치료 종 결 1 년 후 환자는 두통 및 복시를 호소하지 않았고, 비강 내시 경 소견상 재발의 증거는 없었다(Fig. 6).

\section{고 찰}

아스페르길루스는 토양이나 유기물에 흔히 존재하는 기회 감염균으로, 흡인 이후 호흡기내에서 자랄 수 있으며, 당뇨나 과립구 감소증(granulocytopenia) 등과 같은 면역 저하 상황 에서 병원성을 획득할 수 있다. 중추신경계 아스페르길루스 감염은 뇌막염, 뇌염, 뇌농양, 경막하 농양, 진균성 동맥염 등 으로 나타날 수 있다. 아스페르길루스가 중추신경계에 도달 할 수 있는 방법은 크게 세 가지다. 첫째, 비강 및 부비동 등과 같이 인접한 구조를 통하여 도달하는 경우, 둘째, 신경외과 수술 중 의인성으로 감염되는 경우 등과 셋째, 드물지만 호흡 기에 존재하고 있던 균주가 혈행을 통하여 퍼지는 경우 등이 있다. ${ }^{3)}$ 본 증례는 이전에 신경외과 수술의 병력이 없었으며, 컴퓨터단층촬영 및 수술 소견상 비강 및 부비동과 직접적 연 결이 보이지 않아, 혈행성 전파로 인하여 병변이 발생한 것으 로 추정할 수 있을 것이다. 또한, 중추신경계 아스페르길루스 감염은 면역이 저하된 환자에서 주로 발생하지만, 본 증례에 서는 면역 저하의 증거 없이 발생한 것이 특이한 점이다. 수술 장 소견상 주변 조직으로의 침습은 없었고, 비부비동 진균구 와 유사하게 진휽과 같은 내용물이 보여, 비슷한 병태생리를 공유할 것으로 생각된다. 

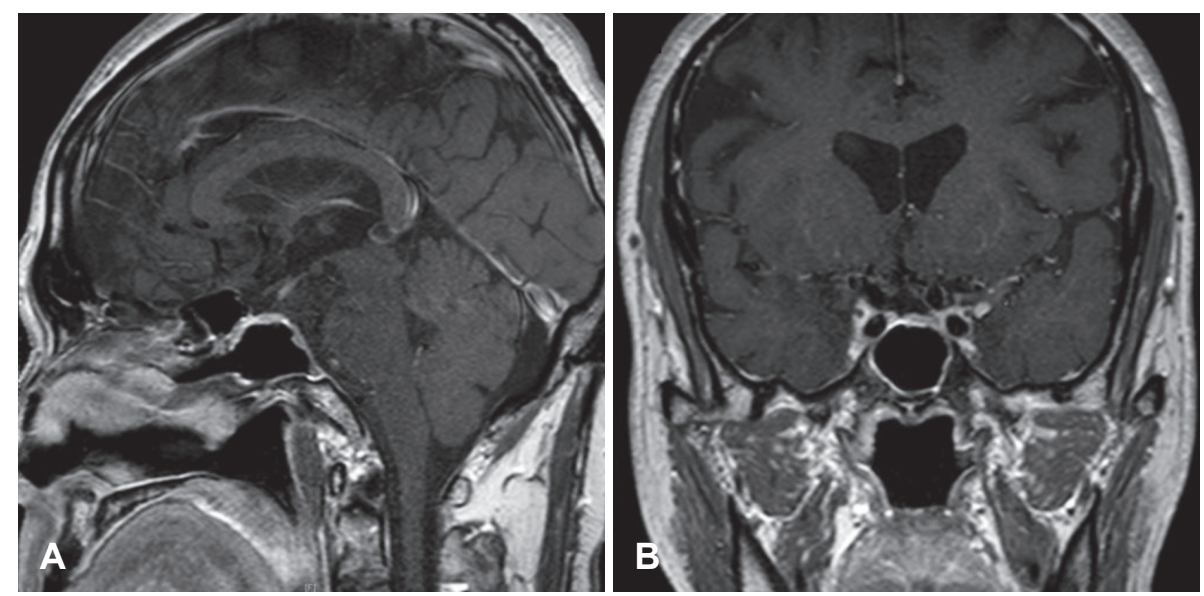

Fig. 5. Two months after operation, the clivus lesion was clear in $\mathrm{T} 1$ weighted MRI (A and $B$ ) and CT (C and D).
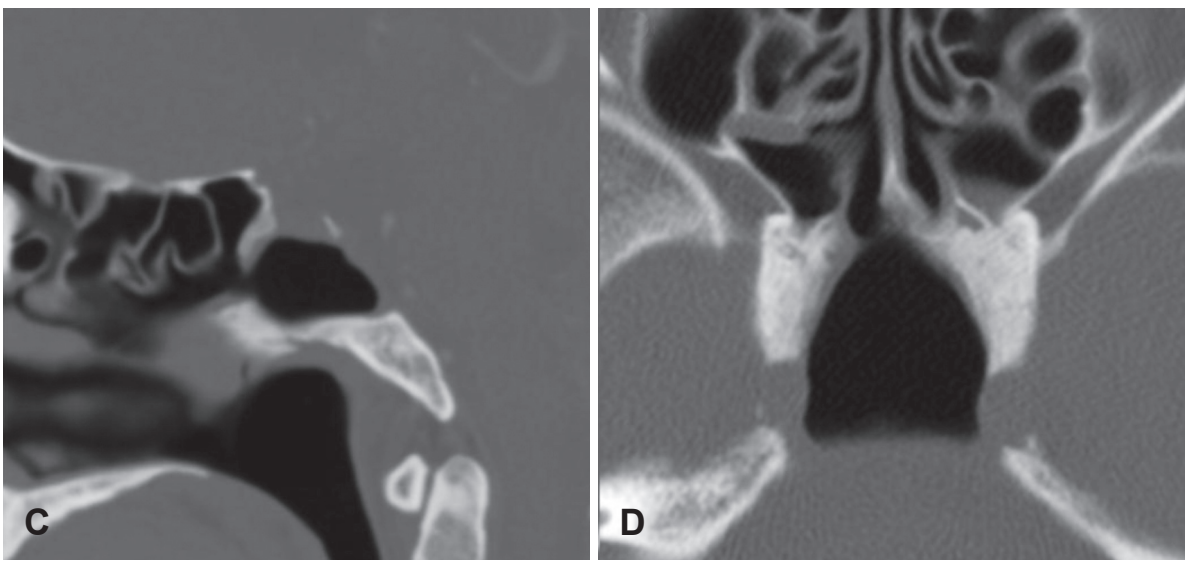

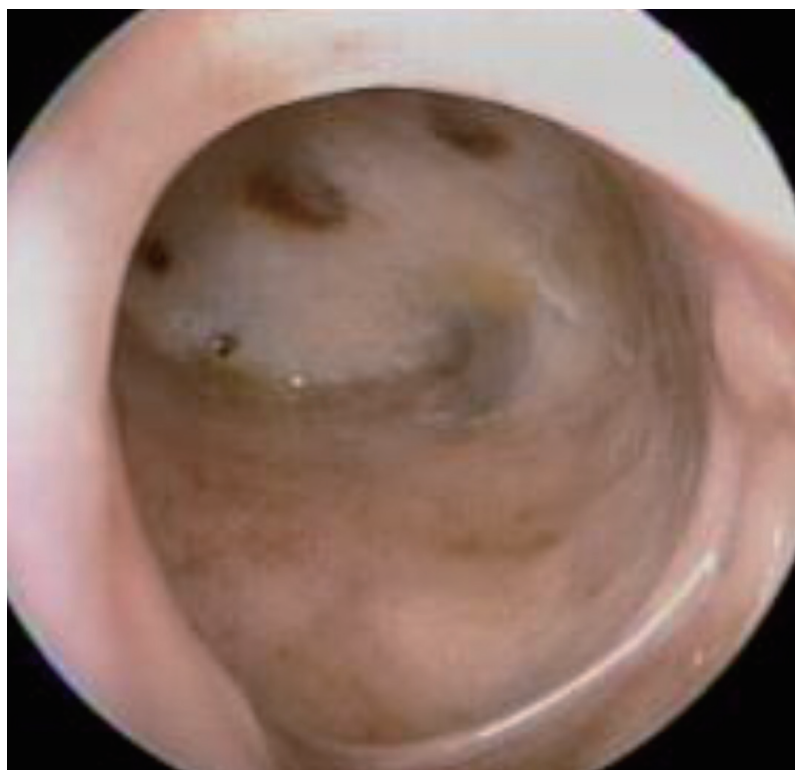

Fig. 6. Endoscopic finding at 1 year after operation: well healed clival abscess cavity and no evidence of recurrence.

자기공명영상이 뇌 기저부의 농양의 진단에 가장 유용한 방법이다. 농양 내부 단백질의 함유 정도에 따라 다르지만 일 반적으로 $\mathrm{T} 1$ 강조영상에서 저 신호강도를 보이며, T2 강조 영
상에서 고 신호강도를 보인다. 본 증례에서는 $\mathrm{T} 1$ 강조영상에 서 고신호 강도를, T2 강조영상에서는 저신호 강도를 보여 보 통의 농양보다는 단백질 함유가 높은 농양임을 짐작할 수 있 었으며, 이는 일반적인 비부비동의 진균구보다는 단백질 함 유가 낮을 경우에 나타나는 소견으로 수술 전 진균성 농양을 의심하기는 어려웠으며 조직검사를 통하여 확진할 수 있었 다. 또한 자기공명영상만을 보았을 때는 접형동에서 기원한 점액낭종일 가능성이 더 높았으나, 전산화단층촬영 이후에 사대에서 기원한 농양일 가능성을 고려하게 된 증례로, 자기 공명영상에서 진단이 되는 경우에서라도 골성 구조의 변화를 판단하여 경 비강 수술적 접근이 고려될 경우에는 반드시 전 산화단층촬영을 시행하는 것이 수술을 안전하게 시행하는 데 중요하겠다. 특히 시상면(sagittal section)을 재구성하여 볼 수 있다면, 주변 구조물과의 관계를 파악하는 데 도움을 받을 수 있다.")

사대(clivus)는 두개저의 중앙에 위치하며 하나로 이루어 진 골성 구조물로서 내경동맥, 시신경, 뇌간, 해면정맥동 등의 중요 구조물들이 인접해 있으며, 이곳에 발생한 병변은 다양 한 뇌신경 합병증-시력저하, 복시, 어지럼 등이 쉽게 발생하며, 수술시 많은 주의를 요하게 된다. ${ }^{5)}$ 사대로 접근하기 위하여 전 
통적으로 개두술을 이용하여 왔으나 최근에는 내시경을 이용 한 경 비강 사대 접근법(endoscopic endonasal clival approach) 이 주로 이용된다. ${ }^{6}$ 사대의 점액낭종은 이전 문헌에 보고된 바 있으나 ${ }^{7,8)}$ 이에 비하여 사대에 일차적으로 발생한 진균성 농양 증례는 보고된 바 없었다. 본 증례에서는 진단 및 배농 술을 위한 내시경적 경 비강 사대 접근법을 이용하여 배농술 및 조직검사를 시행하였고 술 후 환자의 복시와 두통은 완전 히 회복되었다.

중추신경계 진균성 농양에서는 보통 경정맥 amphotericin $\mathrm{B}$ 투여가 추천된다. 이전의 보고에 따르면, 치료되지 않은 중 추신경계 아스페르길루스 감염의 사망률은 $100 \%$ 에 가까우 며, 국소적인 중추신경계 아스페르길루스 감염증에서도 수술 적 배농 및 항진균제 투여에도 불구하고 치료 성공률은 약 $30 \%$ 정도로 매우 치사율이 높은 질환이다. ${ }^{9,10)}$ 본 증례의 경우, 아스페르길루스에 의한 농양 벽이 후두개저의 경막 및 내경 동맥의 경막으로 둘러싸여 있었다. 경막내 병변은 아니므로 엄밀한 의미의 중추신경계 진균성 농양으로 보기는 어려우나, 경막내 파급시 치사율이 매우 높은 위험성을 감안하였을 때, 전신적 항진균제 사용을 하는 것이 합당할 것으로 판단하여 약 3.5 개월간 항진균제를 투여하였으며, 특별한 합병증 없이 치료를 종결할 수 있었다.

영상의학적 검사에서 두개저 농양 혹은 점액낭종이 보였을 경우, 감별진단에 반드시 진균성 농양을 고려해야 한다. 정확 한 진단은 수술을 통한 조직검사를 통해서만 가능하며, 사대 를 비롯한 뇌 기저부의 진균성 농양은 내시경적 경 비강 접근
법을 이용하여 안전하게 수술이 가능하다. 수술 이후에는 전 신적 항진균제 치료를 고려해야 한다.

\section{REFERENCES}

1) Soares-Fernandes JP, Valle-Folgueral JM, Morais N, Ribeiro M, Moreira-da-Costa JA. Diffusion-weighted MR imaging findings in an isolated abscess of the clivus. AJNR Am J Neuroradiol 2008; 29(1):51-2.

2) Kim K, Lim SC. Image-guided surgery in the paranasal sinus and skull base lesion. Korean J Otolaryngol-Head Neck Surg 2006; 49(11):1082-6.

3) Hao L, Jing C, Bowen C, Min H, Chao Y. Aspergillus sellar abscess: case report and review of the literature. Neurol India 2008;56(2): 186-8.

4) Shin JM, Jang WI, Baek BJ. Analysis of Sphenoid Sinus and Surrounding Structures Using Multidetector Computed Tomography. Korean J Otorhinolaryngol-Head Neck Surg 2012;55(2):95-100.

5) Solares CA, Fakhri S, Batra PS, Lee J, Lanza DC. Transnasal endoscopic resection of lesions of the clivus: a preliminary report. Laryngoscope 2005;115(11):1917-22.

6) Fraser JF, Nyquist GG, Moore N, Anand VK, Schwartz TH. Endoscopic endonasal minimal access approach to the clivus: case series and technical nuances. Neurosurgery 2010;67(3 Suppl Operative):ons150-8; discussion ons158.

7) Chua R, Shapiro S. A mucopyocele of the clivus: case report. Neurosurgery 1996;39(3):589-90; discussion 590-1.

8) Fujimoto Y, Harada Y, Toyota S, Wakayama A, So H, Yoshimine T. Primary clival mucocele: case report. Neurol Med Chir (Tokyo) 2011;51(3):250-2.

9) Walsh TJ, Hier DB, Caplan LR. Aspergillosis of the central nervous system: clinicopathological analysis of 17 patients. Ann Neurol 1985; 18(5):574-82.

10) Lee JC, Lim DJ, Ha SK, Kim SD, Kim SH. Fatal case of cerebral aspergillosis: a case report and literature review. J Korean Neurosurg Soc 2012;52(4):420-2 